\title{
PERFORMANCE APPRAISAL SYSTEM: ITS EFFECTIVENESS AND IMPACT ON PERFORMANCE AND JOB SATISFACTION
}

\author{
Anum Khalid \\ Research Scholar, \\ Greenwich University, Karachi, Sindh, \\ Pakistan. \\ Email: anummm.khannn@gmail.com

\section{S. Khurram Khan Alwi} \\ Assistant Professor, \\ Greenwich University, Karachi, Sindh, \\ Pakistan
}

\begin{abstract}
Performance appraisal is a fundamental action for any association that searches for the development and to make the greatest benefit in this regularly expanding focused condition. The principle reason for this performance appraisal is to compute the power of performance appraisal approach towards the workers and furthermore to think about the connection between performance execution and performance examination. To get to worker's execution, performance appraisal is another approach which is usually utilized on associations to get out progressive updates in representative execution. The basic instrument of a significant performance appraisal framework arbitrary, while the present procedure of performance comprises of tolerating the essentials and the fundamental advances that set the association. As we realize that performance appraisal is a mistaken, human process thus it is an extreme errand to effectively incorporate. At the point when performance appraisal framework was first actualized the procedure was non straightforward. Means representatives were not told about their execution. There was no deliberate work out and the total procedure was appraisal holds self-evaluation by the representative also. Along these lines when the framework has enhanced from non-straight forwardness to straightforwardness.
\end{abstract}

\section{KEYWORDS}

Appraisee, Appraiser, Hygiene, Job satisfaction, Motivators, Performance, 


\section{INTRODUCTION}

Each part of authoritative life, from representative occupation execution to techniques for expanding efficiency, is being assessed as associations endeavor to stay focused in nearby, national and even worldwide markets. As requests for magnificence increment and consistency in the work put is tested, the attention on human potential and its viral part as a colossal contributing resource remain ever evident "All organizations must face up to the challenge of how to evaluate, utilize and develop the skills and abilities of their employees to ensure that organizational goals are achieved, and also to ensure that individuals gain as much satisfaction as possible from their jobs while making effective contributions" (Anderson, 1993). The instructive setting is a complex condition; made out of a bunch of identities, assorted educational modules, instructional desires, and responsibility whose primary expectation ought to be the deliverance of value guideline to the understudies. Inside this develop, the educator's part as the essential disseminator of information is basic in the accomplishing of these instructive objectives.

Their mentalities with respect to parts of their activity ought to be considered, and additionally techniques used to assess their execution. While trying to accomplish these increases, successful human asset administration is basic. Sissons (1989) construed that overseeing individuals is a key, most likely the key component, in powerful business arranging. With this consistently expanding accentuation on people within the organization, performance appraisal should then be seen as an important element of effectively managing work attainment and should be viewed as a deliberate strategy to achieving organizational success. Performance appraisal is defined as "the process of identifying, observing, measuring, and developing human performance in organizations" (Schneir \& Beatty, 1982). Each of these elements serve as integral components to the intent of the process. Identification determines what specifically should be analyzed; areas to be studied, performance dimensions, and the evaluative scale used (Schneir \& Beatty, 1982).

Perception ought to accommodate unprejudiced and reasonable judgments of execution. While an instrument holds the way to deciphering these watched goals in task and after that applying essentialness and attractive quality as to their significance in the association, "The scales that raters use to make these 
assessments are. of course, critical. They not only need to be relevant, i.e., based only on identified performance characteristics, but also must be comparable across other raters in the organization"

(Cardy \& Dobbins, 1994).

The last part, advancement, ought to distinguish expertise level of the ratee based on over a wide span of time execution. It ought to likewise saddle and guide this potential as objectives are sketched out for what's to come. The performance appraisal can be viewed as fulfilling two main purposes for the organization: "I the maintenance of organization control, and 2. the measurement of the efficiency with which organization's human resources are being utilized, and the improvement of these resources". (Cummings \& Schwab. 1973). Cummings furthered this argument for performance appraisal by stating that "the organization must first be able to measure performance if it is to successfully influence performance" (Cummings \& Schwab, 1973). Central to this theme was the recognition that the process of goal attainment was through people. Smith and Brouwer (1977) asserted that the performance appraisal process, along with procedures utilized to develop management, constituted the principle medium through which human talent in organizations were most effectively applied. The mere complexity of the performance appraisal, due to the multiple dynamics present in this process, "involves some of the most important aspects of people's sense of who they are and what they can be, since it deals with their competence and effectiveness most of all, perhaps, it is an interaction between two human beings, who often are nervous, tense, defensive to some degree, poorly prepared to talk about such important issues, and full of their own misperceptions, biases, hopes and values" (Mohrman, Resnick \& Lawler, 1989).

Individuals often align their perceptions of self with their job, and if the performance appraisal is negative, their sense of self-worth and importance may be adversely impacted. The implications of this appraisal, then, may have resulting negative effects on not only self-perception, but job motivation, performance, worker collegiality, communication and overall resistance to change in the organization. The test is to use an execution examination framework that will impartially assess execution while achieving a more noteworthy feeling of occupation fulfillment for the worker. 
Through the procedure of distinguishing proof, perception, estimation, and advancement, the goal, at that point of the execution examination ought to be to eventually enhance execution while at the same time taking out the negative results. Subsequently, a viable execution evaluation framework ought to achieve enhanced execution as a consequence of its advantages to an association.

However critical the performance appraisal system is deemed by the organization, the individual impacted by this evaluative process may hold a different perspective of its importance. The resulting attitude and displayed behavior, be it positive or negative, may indeed be a result of the performance appraisal process. Employees' resulting job satisfaction or dissatisfaction may be an affective reaction to this judgmental facet of their job performance. Change in the nature of work life is alluring, along these lines bringing about the achievement of association objectives, and also accomplishing a person's sure reaction to the workplace. Subsequently, worker work fulfillment is wanted for the wellbeing and feasibility of the association Employment fulfillment, indistinct in idea, has no sweeping hypothesis of thought pertinent to each circumstance. Early perspectives on work fulfillment held that laborers had as it were a generally speaking or worldwide sentiment of fulfillment about their work.

Current idea focuses to particular parts of the activity including the work itself, pay, collaborators, et cetera as contributing variables to work fulfillment or disappointment (Balzer and Smith, 1990). Locke assisted this line of reasoning as he saw work fulfillment as the consequence of the collaboration of one's qualities and one's impression of the activity and its condition (Locke, 1969). His definition is: Job satisfaction is the pleasurable emotional state resulting from the appraisal of one's job as achieving or facilitating the achievement of one's job values. Job dissatisfaction is the un pleasurable emotional state resulting from the appraisal of one's job as frustrating or blocking the attainment of one's job's values. Job satisfaction and job dissatisfaction are a function of the perceived relationship between what one wants from one's job and what one perceives it offering or entailing (Locke, 1969). The previous quite a few years have offered an expansion in the examination on work fulfillment. Hoppock saw work fulfillment as "any mix of physiological, mental, and ecological conditions that causes a man honestly to state, I am happy with my activity" (Hoppock, 1935). At the point when seen as a needy 
variable, Hopkins demonstrated that activity fulfillment was achieved by different conditions, for example, the nature of the activity and individual qualities of the activity that are available (Hopkins, 1983).Frederick Herzberg trusted that the reasons for work fulfillment were particular and unmistakable from the elements that prompted work disappointment (Herzberg, 1966). The two-factor hypothesis of occupation fulfillment fought that factors that satisfied a person's requirement for mental development added to work fulfillment. These substance factors were marked as helpers. Components that added to work disappointment were identified with work setting (the conditions under which the employments were being performed). These setting factors were named as cleanliness factors. Herzberg proposed that by expanding the sparks rather than the cleanliness factors in a work circumstance, the worker could encounter more prominent employment fulfillment, which thusly, could eventually enhance his activity execution. Herzberg trusted that the association should endeavor to fulfill a person's inborn needs for he felt that "The primary functions of any organization, whether religious, political or industrial, should be to implement the needs for man to enjoy a meaningful existence" (Herzberg, 1966).

The focal reason for this examination was to gauge instructors' activity fulfillment levels with their view of the value of forced execution evaluations. Execution evaluations, in a perfect world ought to be utilized as an intercession system that decidedly affected workers' activity execution, unmistakably characterized their part in the association, set rules and techniques for development, and at last restored workers' dedication and bonds to the association. People in associations require genuine assessment to enhance their execution. They additionally could should be given with bearing. Be that as it may, there may be issues in leading execution evaluations. Key to the comprehension of this procedure, was the need to perceive factors that could at last effect the evaluator's judgment and choices, and in addition the effect that this execution examination may have on the individual being assessed unmistakably, the propriety in the choice of the evaluator was pivotal. Regularly, the part of assessment was relegated to the prompt line manager whose judgment may be affected independent from anyone else intrigue, authoritative legislative issues and how much the evaluator had faith in the legitimacy and value of the examination. This judgmental assessment of a person's activity execution could have constrained down to earth use, in light of a variety of conditions. The low quality of the assessment, mercy of the 
appraiser, inspiration to precisely assess the ratee's execution, statistic predispositions, and the attitude and demeanor of the rater may affect the assessment process. There is a requirement for execution examination frameworks to kill the presence of human blunder and predisposition in judgment.

The execution evaluation, frequently is seen as unimportant what's more, ailing in work arrangement, and ought to be given significance by the association. This evaluative process, distinguishing destinations and norms of execution, ought to be commonly settled upon, along these lines shielding against negative reactions from either party. The execution evaluation, to be esteemed powerful, ought to be seen by all as a basic part of employment execution. Meeting these conditions can give a fundamental establishment to lead an execution examination, be that as it may, the effect on the evaluate to change and eventually enhance execution may not be figured it out.

The examination, whose expectation is to give a legitimate assessment of work execution, may bring out a contrary response that could obstruct and contrarily affect execution when it didn't meet the desire level of the evaluate. The evaluate may create sentiments of open antagonistic vibe, outrage, and protectiveness and could challenge even the scarcest remark apparent as negative. Rather than enhanced work execution and thoughtfulness regarding conduct requiring change, a stressed workplace may result, where, disdain, absence of trust; with the likelihood of unwanted conduct surfacing.

Previous studies Lawler \& Porter in Mankin, Ames, Jr. \& Grodsky (1980) have indicated that employees who experienced higher levels of job satisfaction could be more productive than those who were dissatisfied with their job. Frederick Herzberg's motivation-hygiene theory attributed the existence of certain factors leading to job satisfaction or job dissatisfaction. Research on the person's impression of the estimation of the execution evaluation as impacting element of his / her level of employment fulfillment was constrained. An investigation endeavoring to quantify a person's activity fulfillment levels with their view of the value of forced execution examinations could furnish administration with an extra asset for deciphering shifting execution levels among representatives with a similar activity grouping. 


\section{OBJECTIVES}

1. To determine the effectiveness of performance appraisal.

2. Its impact on performance and job satisfaction.

\section{RESEARCH QUESTIONS}

1. What are the objectives of performance appraisal?

2. What are essential steps that are important for an effective performance appraisal system?

3. How the process of performance appraisal is beneficial to the organization?

\section{RESEARCH METHODOLOGY}

The study surveyed teachers as respondents. Study is basically related to the effectiveness and impact of performance appraisal on performance and job satisfaction. I distributed questionnaire and ask teachers of different age groups, different years of experience and different level of qualification questions related to performance appraisal system. According to majority of the teachers performance appraisal system is best suited to meet the organizational goals and it has a deep impact on the work performance of a person. Teachers loved to have a fixed duration set for it. Over all when it comes to a teachers choice they would prefer that a satisfying performance appraisal techniques should be adopted for an organization. The information collected from questionnaire was organized and statistical computations were done to explore the relationship between different variables. Responses from questions were fed into computer and analyzed using SPSS software. Descriptive statistics was applied to compute the percentage and frequency distribution of the respondents on the variables. Finally, the results are summarized and meaningful interpretations of result are made to present the conclusions.

\section{Demographic distribution of the sample}

The study focuses on teachers with different years of experience (less than a year, 1-5 years, 6-10 years and 10 and above). Different educational qualification (Inter, bachelor, professional teaching degree and masters) Age group ranging from (18-25years, 26-35years, 36-45 and 46 and above).

\section{Population, sampling size and sampling techniques}

It is a convenient sampling method and a questionnaire was distributed among 80 teachers. The targeted population is the school teachers of private school 
Karachi. Sampling is done at DHA school Foundation Public School by using convenient sampling method.

\section{RESEARCH DESIGN}

We are analyzing the impact of performance appraisal system on work performance and job satisfaction. It is a quantitative analysis. The study analyzed data collected from 50 teachers of a private school named Foundation Public School in the area of defense. These teachers were participants in a professional development experience. Questionnaire was used as a research instrument. Teachers were asked to complete a questionnaire. Questions were related to teacher's perception about performance appraisal. 3 types of demographic attributes were given related to different years of experience, different level of educational qualification and age group ranging from 18 till 46 and above. Data was collected from the teachers and it was analyzed through SPSS and interpretations was mentioned. Results and discussions were done on the basis of the analysis and interpretations.

\section{Procedure of the study in data collection}

First, I went for the history and different strategies used for performance appraisal system. As I am working in Foundation Public School so it was easier for me to collect data through questionnaire. I looked for acceptance level what are the opinions of teachers regarding the performance appraisal system.

\section{DATA ANALYSIS \& RESULTS}

Analysis is done by categorizing the data into 3 parts. First part refers to years of service with the current organization. Second part relates all the queries with different age levels while the third part defines all queries related to different educational levels. Following are the interpretations made from the data.

\section{Interpretations}

Years of service with the current organization:

Table No. 1

\begin{tabular}{|c|c|}
\hline \multicolumn{2}{|l|}{$\begin{array}{r}\text { performan } \\
\text { chnique of } n\end{array}$} \\
\hline $\begin{array}{l}\text { strongly Agree } \\
\text { disagree }\end{array}$ & $\begin{array}{l}\text { strongly } \\
\text { agree }\end{array}$ \\
\hline
\end{tabular}




\begin{tabular}{|c|c|c|c|c|c|}
\hline \multirow{4}{*}{$\begin{array}{l}\text { Years of service with current } \\
\text { organization }\end{array}$} & less than & 0 & 6 & 1 & 7 \\
\hline & $\begin{array}{l}\text { a year } \\
1-5 \text { years }\end{array}$ & 0 & 9 & 7 & 16 \\
\hline & $6-10$ & 0 & 9 & 10 & 19 \\
\hline & $\begin{array}{l}\text { years } \\
10 \text { and } \\
\text { above }\end{array}$ & 1 & 5 & 2 & 8 \\
\hline Total & & 1 & 29 & 20 & 50 \\
\hline
\end{tabular}

The analysis in this table shows relation between years of service with the current organization and awareness of the performance appraisal technique of the organization. From the teachers who have worked less than a year 6 agreed and 1 strongly agreed to the point. Amongst the teachers working more than 1 $1 / 2$ years 9 agreed and 7 strongly agreed. Majority teachers who have worked from 6-10 years agreed to the point. Out of 50, 8 number of teachers who have worked more than 10 years agreed to this point.

Table No. 2

\begin{tabular}{|c|c|c|c|c|}
\hline & \multirow[b]{3}{*}{ less than a year } & \multicolumn{2}{|c|}{$\begin{array}{l}\text { Q2: Are you aware of } \\
\text { the objective of the } \\
\text { performance appraisal } \\
\text { system }\end{array}$} & \multirow[t]{2}{*}{ Total } \\
\hline & & agree & strongly agree & \\
\hline & & 7 & 0 & 7 \\
\hline Years of service with current & $1-5$ years & 9 & 7 & 16 \\
\hline organization & $6-10$ years & 11 & 8 & 19 \\
\hline & 10 and above & 5 & 3 & 8 \\
\hline Total & & 32 & 18 & 50 \\
\hline
\end{tabular}

Table 2 gives a relation of years of service with the current organization and awareness of the objective of performance appraisal system. 7 teachers who worked less than a year agreed to the point. 9 teachers who worked more than $1 \frac{1}{2}$ years agreed and 7 strongly agreed. Majority teachers who worked under 610 years agreed to it. However, 5 number of teachers who worked more than 10 years and above agreed and 3 strongly agreed.

\section{Table No. 3}

Q3: Performance appraisal system helps Total organization in achieving goals 


\begin{tabular}{llcccccc}
\hline & & disagree & Neither & agree & strongly agree & \\
\cline { 2 - 5 } & $\begin{array}{l}\text { less than } \\
\text { a year }\end{array}$ & 1 & 3 & 3 & & 0 & 7 \\
Years of & $1-5$ years & 0 & 4 & 6 & 6 & 16 \\
$\begin{array}{l}\text { service with } \\
\text { current } \\
\text { organization }\end{array}$ & $\begin{array}{l}6-10 \\
\text { years }\end{array}$ & 1 & 3 & 10 & 5 & 19 \\
$\begin{array}{l}10 \text { and } \\
\text { above }\end{array}$ & 0 & 1 & 5 & 2 & 8 \\
Total & 2 & 11 & 24 & 13 & 50 \\
\hline
\end{tabular}

Table 3 compares relation between years of service with the current organization and performance appraisal system helps organization in achieving goals. 1 teacher working less than a year disagreed, 3 neither and 3 agreed the point. The count for teachers working for more than $1 \frac{1}{1} 2$ was 4 neither, 6 agreed and 6 strongly agreed. Teachers who worked under 6-10 years showed that 1 disagreed, 3 neither, 10 agreed and 5 strongly agreed.

Table No. 4

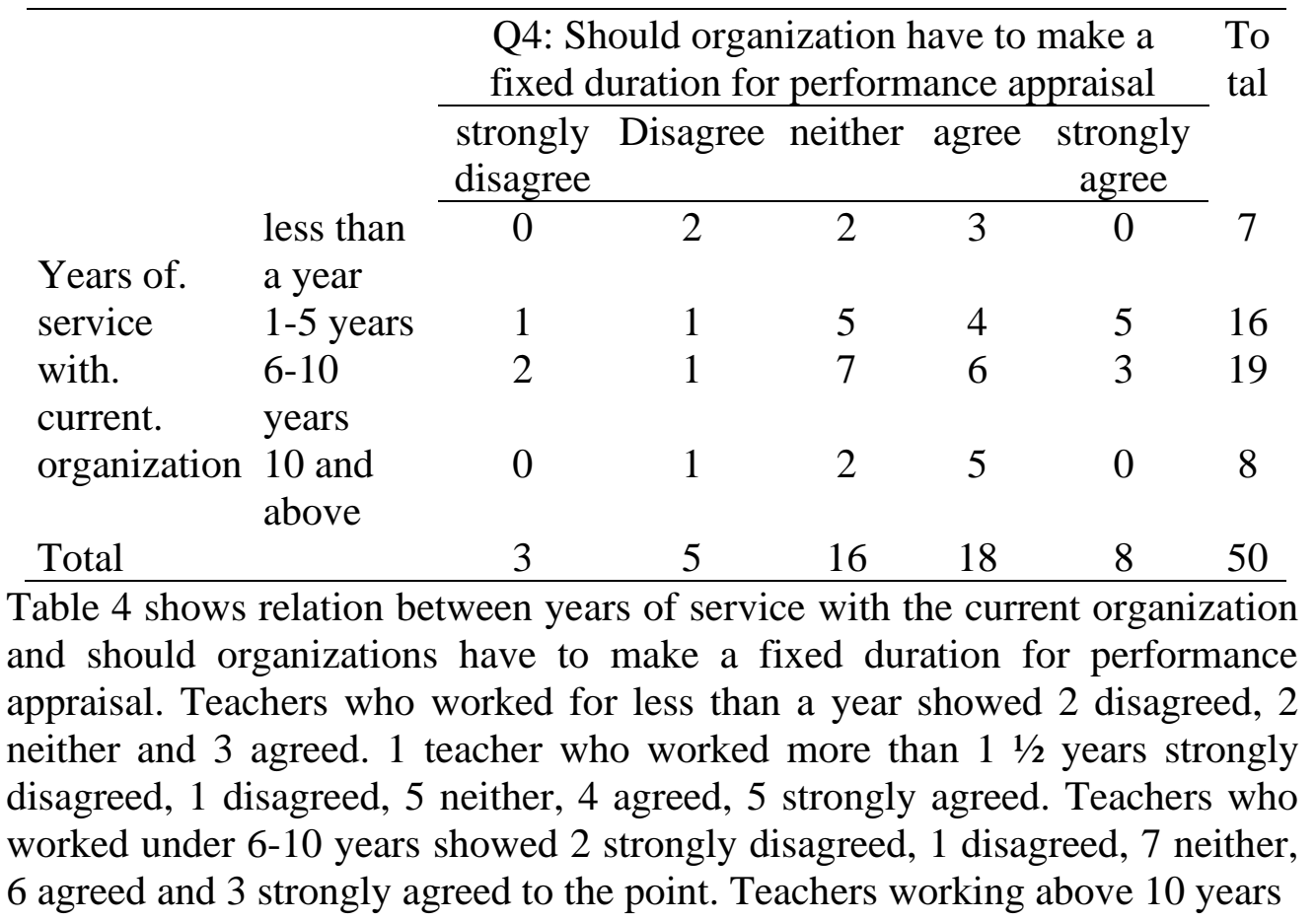


showed 1 disagreed, 2 neither 5 agreed.

Table No. 5

\begin{tabular}{|c|c|c|c|c|c|}
\hline & & $\begin{array}{r}\text { Q5: I } \\
\text { apprecic } \\
\text { yo }\end{array}$ & $\begin{array}{l}\text { it impc } \\
\text { tion for } \\
\text { r co-wo } \\
\text { super }\end{array}$ & $\begin{array}{l}\text { ant to get } \\
\text { our work by } \\
\text { er and } \\
\text { or }\end{array}$ & Total \\
\hline & & neither & agree & $\begin{array}{c}\text { strongly } \\
\text { agree }\end{array}$ & \\
\hline & $\begin{array}{l}\text { less than a } \\
\text { year }\end{array}$ & 0 & 7 & 0 & 7 \\
\hline Years of service with & $1-5$ years & 0 & 8 & 8 & 16 \\
\hline current organization & $6-10$ years & 2 & 12 & 5 & 19 \\
\hline & $\begin{array}{l}10 \text { and } \\
\text { above }\end{array}$ & 2 & 5 & 1 & 8 \\
\hline Total & & 4 & 32 & 14 & 50 \\
\hline
\end{tabular}

Table 5 gives analysis about is it important to get appreciation for your work by your co-worker and supervisor. 7 teachers who worked less than a year agreed to this point. 8 agreed and 8 strongly agreed who worked more than $1 \frac{1}{2}$ years. Teachers who worked under 6-10 years showed 2 neither, 12 agreed and 5 strongly agreed. Teachers who have worked for 10 and above showed 2 neither, 5 agreed and 1 strongly agreed.

Table No. 6

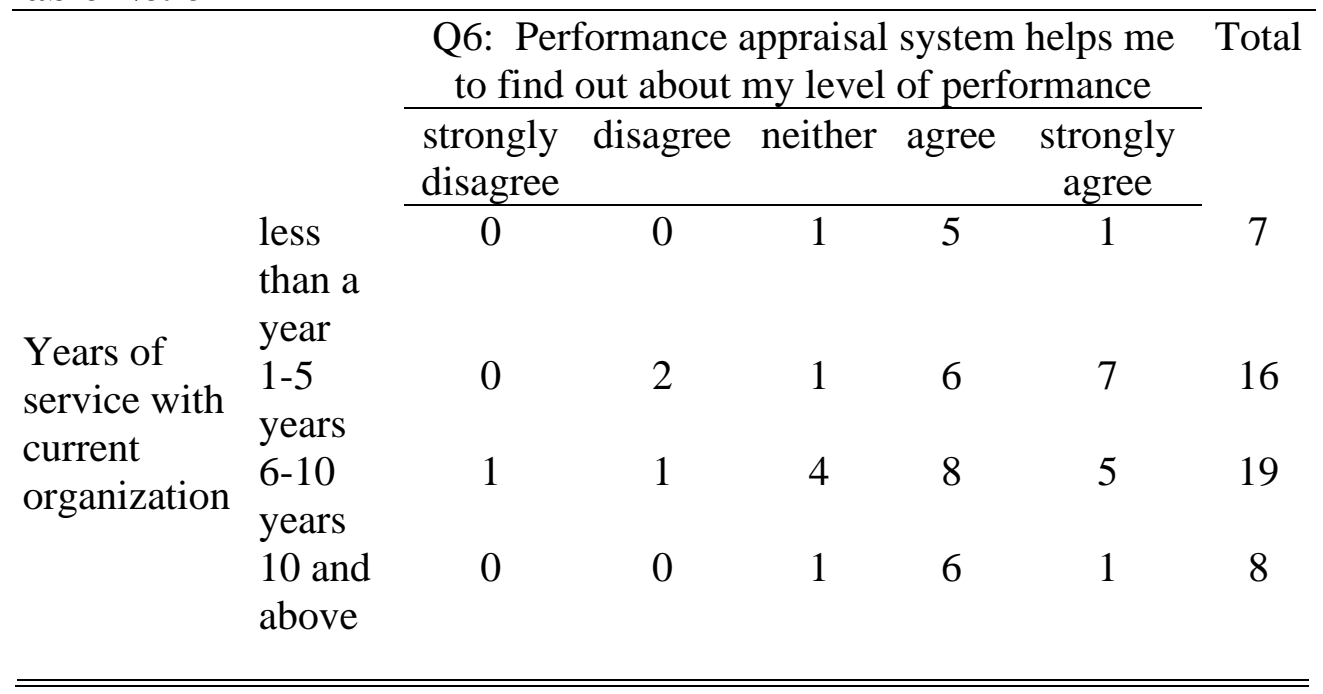


Pakistan Journal of Educational Research, Vol 1, Issue 2 (2018) Performance appraisal...

Total

$\begin{array}{llll}1 & 3 & 7 & 25\end{array}$

14

Table 6 gives analysis of performance appraisal system helps me to find out about my level of performance. People who worked less than year showed 1 neither, 5 agreed and 6 strongly agreed. People who worked more than $1 \frac{1}{2}$ years showed 2 disagreed, 1 neither, 6 agreed and 7 strongly agreed. Teachers who worked under 6-10 years showed 1 strongly disagreed, 1 disagreed, 4 neither, 8 agreed and 5 strongly agreed. Teachers working for 10 and above shows 1 neither, 6 agreed and 1 strongly agreed.

Table No. 7

\begin{tabular}{|c|c|c|c|c|c|c|c|}
\hline & & $\begin{array}{r}\text { Q7: I a } \\
\text { be }\end{array}$ & $\begin{array}{l}\text { ways reac } \\
\text { ause of } p\end{array}$ & $\begin{array}{l}\text { my per } \\
\text { forman }\end{array}$ & $\begin{array}{l}\text { orman } \\
\text { e apprs }\end{array}$ & $\begin{array}{l}\text { e target } \\
\text { isal }\end{array}$ & Total \\
\hline & & $\begin{array}{l}\text { strongly } \\
\text { disagree }\end{array}$ & disagree & neither & agree & $\begin{array}{c}\text { strongly } \\
\text { agree }\end{array}$ & \\
\hline & $\begin{array}{l}\text { less } \\
\text { than a } \\
\text { year }\end{array}$ & 0 & 0 & 1 & 5 & 1 & 7 \\
\hline $\begin{array}{l}\text { Years of } \\
\text { service with }\end{array}$ & $\begin{array}{l}1-5 \\
\text { years }\end{array}$ & 0 & 2 & 3 & 7 & 4 & 16 \\
\hline $\begin{array}{l}\text { current } \\
\text { organization }\end{array}$ & $\begin{array}{l}6-10 \\
\text { years }\end{array}$ & 1 & 0 & 5 & 10 & 3 & 19 \\
\hline & $\begin{array}{l}10 \text { and } \\
\text { above }\end{array}$ & 0 & 0 & 0 & 7 & 1 & 8 \\
\hline Total & & 1 & 2 & 9 & 29 & 9 & 50 \\
\hline
\end{tabular}

Table 7 shows analysis of I always reach my performance target because of performance appraisal. Teachers working less than a year shows 1 neither, 5 agree and 1 strongly agree. Teachers who worked for more than $11 / 2$ years showed 2 disagreed, 3 neither, 7 agreed and 4 strongly agreed to the point. Teacher who are working under 6-10 years stated 1 strongly disagreed, 5 neither, 10 agreed and 3 strongly agreed. Teachers who are working 10 and above showed 7 agreed and 1 strongly agreed to the point.

Table No. 8

Q8: Performance appraisal motivates Total

employee to make sound decisions and

appropriate choices 


\begin{tabular}{|c|c|c|c|c|c|c|c|}
\hline & & $\begin{array}{l}\text { strongly } \\
\text { disagree }\end{array}$ & disagree & ther & gree & & \\
\hline & $\begin{array}{l}\text { less than } \\
\text { a year }\end{array}$ & 1 & 1 & 2 & 3 & 0 & 7 \\
\hline $\begin{array}{l}\text { Years of } \\
\text { service with }\end{array}$ & $\begin{array}{l}1-5 \\
\text { years }\end{array}$ & 0 & 3 & 7 & 5 & 1 & 16 \\
\hline current & $6-10$ & 3 & 1 & 7 & 7 & 1 & 19 \\
\hline organization & $\begin{array}{l}\text { years } \\
10 \text { and } \\
\text { above }\end{array}$ & 0 & 1 & 2 & 5 & 0 & 8 \\
\hline Total & & 4 & 6 & 18 & 20 & 2 & 50 \\
\hline $\begin{array}{l}\text { Table } 8 \text { giv } \\
\text { employees to } \\
\text { less than a yea } \\
\text { to it. Teacher } \\
\text { agreed and } 1 \mathrm{~s} \\
\text { strongly disag } \\
10 \text { and above }\end{array}$ & $\begin{array}{l}\text { es analys } \\
\text { make sour } \\
\text { ar stated } 1 \\
\text { working } \mathrm{f} \\
\text { strongly aq } \\
\text { yreed, } 1 \text { di } \\
\text { showed } 1\end{array}$ & $\begin{array}{l}\text { s about } \\
\text { d decision } \\
\text { strongly di } \\
\text { or more th } \\
\text { reed. Teac } \\
\text { agreed, } 2 \\
\text { disagreed, }\end{array}$ & $\begin{array}{l}\text { performan } \\
\text { s and appr } \\
\text { isagreed, } 1 \\
\text { an } 11 / 2 \text { yea } \\
\text { hers worki } \\
\text { neither an } \\
2 \text { neither a }\end{array}$ & $\begin{array}{l}\text { gree } \\
\text { tated } \\
\text { ander }\end{array}$ & $\begin{array}{l}\text { al } \\
\text { ces. } \\
2 \text { ne } \\
\text { disa } \\
10 \text { J } \\
\text { Tea }\end{array}$ & $\begin{array}{l}3 \\
\text { ne }\end{array}$ & $\begin{array}{l}\text { vates } \\
\text { king } \\
\text { reed } \\
\text { er, } 5 \\
\text { ws } 3 \\
\text { g for }\end{array}$ \\
\hline
\end{tabular}

Table No. 9

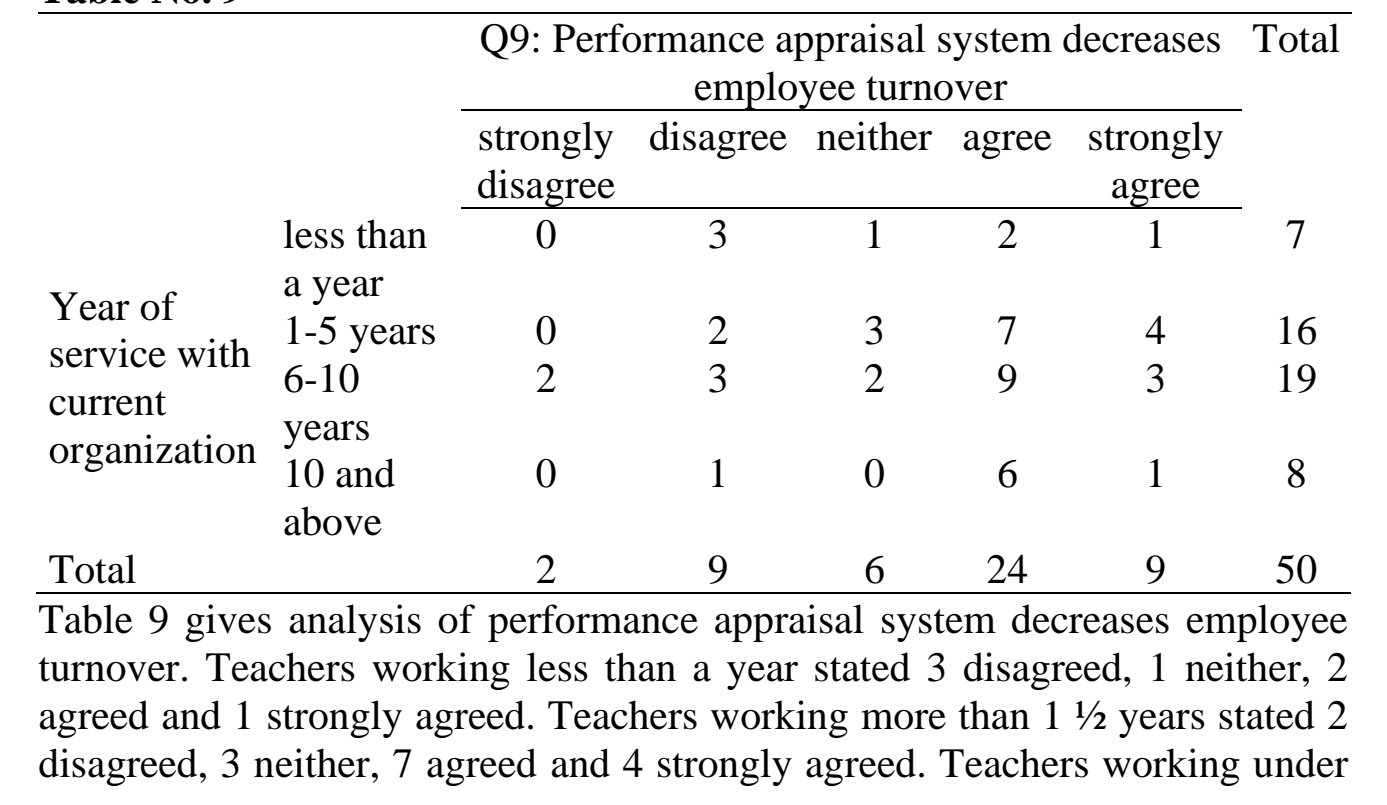


6-10 years gave views 1 disagreed, 6 agreed and 1 strongly agreed. Teacher's working for 10 and above stated 1 disagreed, 6 agreed and 1 strongly agreed.

Table No. 10

\begin{tabular}{|c|c|c|c|c|c|c|c|}
\hline & \multicolumn{5}{|c|}{$\begin{array}{l}\text { Q10: Performance appraisal system satisfies } \\
\text { the employee with the opportunity to get a } \\
\text { better position in the organization }\end{array}$} & \multirow[t]{2}{*}{ Total } \\
\hline & & $\begin{array}{l}\text { strongly } \\
\text { disagree }\end{array}$ & disagree & neither & Agree & $\begin{array}{c}\text { strongly } \\
\text { agree }\end{array}$ & \\
\hline \multirow{4}{*}{$\begin{array}{l}\text { Years of. } \\
\text { service with. } \\
\text { current. } \\
\text { organization }\end{array}$} & $\begin{array}{l}\text { less } \\
\text { than a }\end{array}$ & 0 & 3 & 1 & 2 & 1 & 7 \\
\hline & $\begin{array}{l}\text { year } \\
1-5 \\
\text { years }\end{array}$ & 0 & 5 & 3 & 5 & 3 & 16 \\
\hline & $\begin{array}{l}6-10 \\
\text { years }\end{array}$ & 1 & 4 & 2 & 10 & 2 & 19 \\
\hline & $\begin{array}{l}10 \text { and } \\
\text { above }\end{array}$ & 0 & 1 & 0 & 6 & 1 & 8 \\
\hline Total & & 1 & 13 & 6 & 23 & 7 & 50 \\
\hline
\end{tabular}

Table 10 shows performance appraisal satisfies the employees with opportunity to get a better position in the organization. Teachers working less than a year stated 3 disagreed, 1 neither, 2 agreed and 1 strongly agreed. Teachers working more than 1-5 years showed 5 disagreed, 1 neither, 2 agreed and 1 strongly agreed. Teachers working under 6-10 years showed 1 strongly disagreed, 1 disagreed, 6 agreed and 1 strongly agreed. Teachers working 10 and above stated 1 disagreed, 6 agreed and 1 strongly agreed.

Table No. 11

\begin{tabular}{|c|c|c|c|c|c|}
\hline & \multicolumn{3}{|c|}{$\begin{array}{l}\text { Q1: I am aware of the } \\
\text { performance appraisal } \\
\text { technique of my organization }\end{array}$} & \multirow[t]{2}{*}{ Total } \\
\hline & & $\begin{array}{l}\text { strongly } \\
\text { disagree }\end{array}$ & Agree & $\begin{array}{c}\text { strongly } \\
\text { agree }\end{array}$ & \\
\hline \multirow{3}{*}{ Age } & $18-25$ & 0 & 2 & 0 & 2 \\
\hline & 26-35 & 0 & 13 & 7 & 20 \\
\hline & $36-45$ & 0 & 10 & 10 & 20 \\
\hline
\end{tabular}


Pakistan Journal of Educational Research, Vol 1, Issue 2 (2018) Performance appraisal. .

$\begin{array}{lllll}46 \text { and } & 1 & 4 & 3 & 8\end{array}$

above

$\begin{array}{lllll}\text { Total } & 1 & 29 & 20 & 50\end{array}$

The analysis of this table shows that only teachers of age between 18-25 agreed to the point while 13 teachers ranging between age of 26-35 agreed and 7 strongly agreed. 10 teachers ranging between 36-45 agreed and 10 strongly agreed. Teachers of age 46 and above stated that 1 strongly disagreed, 4 agreed and 3 strongly agreed.

Table No. 12

\begin{tabular}{|c|c|c|c|c|}
\hline & \multicolumn{2}{|c|}{$\begin{array}{l}\text { Q2: Are you aware of the } \\
\text { objective of the } \\
\text { performance appraisal } \\
\text { system }\end{array}$} & \multirow[t]{2}{*}{ Total } \\
\hline & & Agree & strongly agree & \\
\hline \multirow{4}{*}{ age } & $18-25$ & 2 & 0 & 2 \\
\hline & $26-35$ & 16 & 4 & 20 \\
\hline & $36-45$ & 10 & 10 & 20 \\
\hline & $\begin{array}{l}46 \text { and } \\
\text { above }\end{array}$ & 4 & 4 & 8 \\
\hline Tota & & 32 & 18 & 50 \\
\hline
\end{tabular}

The table shows that how many teachers are aware of the objective of the performance appraisal system. This table shows that 2 teachers ranging between 18-25 agreed to the point. 16 teachers ranging from 26-35 agreed and 4 strongly agreed to it. 10 teachers ranging from 36-45 agreed and 10 strongly agreed. 4 teachers ranging between 46 and above agreed and 4 strongly agreed.

Table No. 13

\begin{tabular}{|c|c|c|c|c|c|c|}
\hline & \multicolumn{4}{|c|}{$\begin{array}{l}\text { Q3: Performance appraisal system helps } \\
\text { organization in achieving goals }\end{array}$} & \multirow[t]{2}{*}{ Total } \\
\hline & & disagree & neither & agree & strongly agree & \\
\hline \multirow{4}{*}{ age } & $18-25$ & 0 & 2 & 0 & 0 & 2 \\
\hline & $26-35$ & 1 & 5 & 8 & 6 & 20 \\
\hline & $36-45$ & 1 & 4 & 10 & 5 & 20 \\
\hline & $\begin{array}{l}46 \text { and } \\
\text { above }\end{array}$ & 0 & 0 & 6 & 2 & 8 \\
\hline Total & & 2 & 11 & 24 & 13 & 50 \\
\hline
\end{tabular}


This table shows that what are the views of teachers that how performance appraisal system helps organization in achieving goals. The table shows that 2 teachers aging between 18-25 responded neither. 1 teacher between 26-35 disagreed, 5 neither, 8 agreed and 6 strongly agreed to this point. Teachers ranging between 36-45 years stated 1 disagreed, 4 neither, 10 agreed and 5 strongly agreed. 6 teachers 46 and above agreed and 2 strongly agreed to it.

\section{Table No. 14}

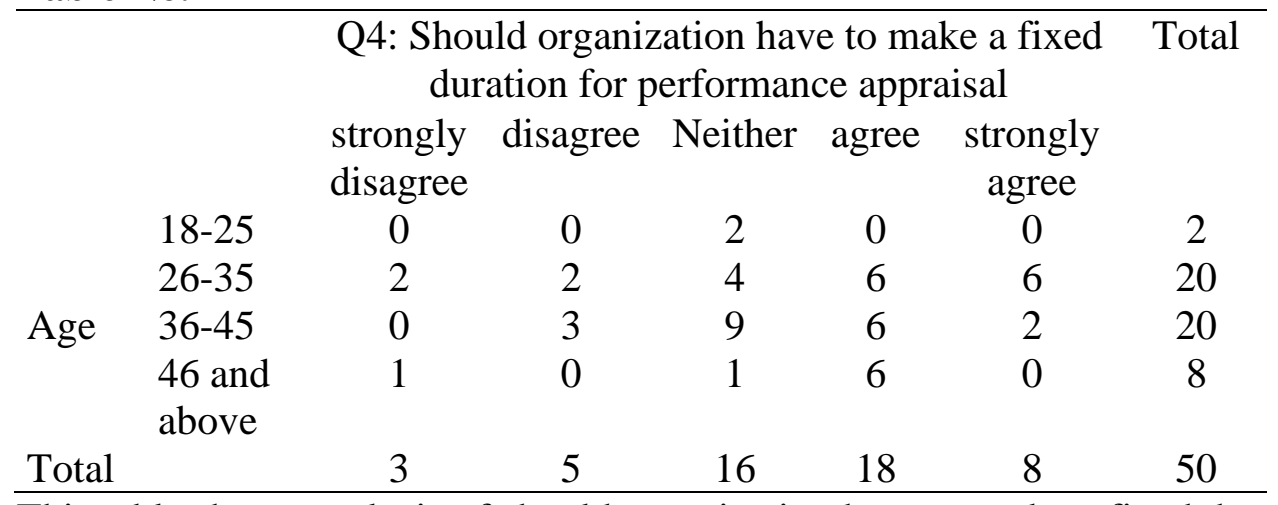

This table shows analysis of should organization have to make a fixed duration for performance appraisal. 2 teachers of 18-25 years of age responded neither. 2 teachers of 26-35 strongly disagreed, 2 disagreed, 4 responded neither, 6 agreed and 6 strongly agreed. Teachers between 36-45 stated 3 disagreed, 9 neither, 6 agreed and 2 strongly agreed.1 teacher 46 and above strongly disagreed, 1 neither and 6 agreed.

Table No. 15

\begin{tabular}{|c|c|c|c|c|c|}
\hline & \multicolumn{3}{|c|}{$\begin{array}{l}\text { Q5: Is it important to get } \\
\text { appreciation for your work by your } \\
\text { co-worker and supervisor }\end{array}$} & \multirow[t]{2}{*}{ Total } \\
\hline & & neither & agree & strongly agree & \\
\hline \multirow{4}{*}{ Age } & $18-25$ & 0 & 2 & 0 & 2 \\
\hline & $26-35$ & 2 & 10 & 8 & 20 \\
\hline & $36-45$ & 1 & 13 & 6 & 20 \\
\hline & 46 and above & 1 & 7 & 0 & 8 \\
\hline Total & & 4 & 32 & 14 & 50 \\
\hline
\end{tabular}

This table analyze that is it important to get appreciation for your work by your co-worker and supervisor. Only 2 teachers between 18-25 agreed to the point. 
2 teachers responded neither, 10 agreed and 8 strongly agreed between age group of 26-35. Teachers between 36-45 showed 1 neither, 13 agreed and 6 strongly agreed. Teachers of 46 and above stated 1 neither and 7 agreed.

Table No. 16

\begin{tabular}{|c|c|c|c|c|c|c|c|}
\hline & \multicolumn{5}{|c|}{$\begin{array}{l}\text { Q6: Performance appraisal system helps me to } \\
\text { find out about my level of performance }\end{array}$} & \multirow[t]{2}{*}{ Total } \\
\hline & & $\begin{array}{l}\text { strongly } \\
\text { disagree }\end{array}$ & disagree & Neither & Agree & $\begin{array}{l}\text { strongly } \\
\text { agree }\end{array}$ & \\
\hline \multirow{4}{*}{ age } & $18-25$ & 0 & 0 & 0 & 2 & 0 & 2 \\
\hline & $26-35$ & 1 & 2 & 3 & 8 & 6 & 20 \\
\hline & $36-45$ & 0 & 1 & 3 & 10 & 6 & 20 \\
\hline & $\begin{array}{l}46 \text { and } \\
\text { above }\end{array}$ & 0 & 0 & 1 & 5 & 2 & 8 \\
\hline Total & & 1 & 3 & 7 & 25 & 14 & 50 \\
\hline
\end{tabular}

This table shows analysis about performance appraisal system helps employee to find about their level of performance. Out of 50 only 2 teachers ranging between 18-25 agreed to the point. Teachers between 26-35 stated 1 strongly disagreed, 2 disagreed, 3 neither, 8 agreed and 6 strongly agreed. Teachers between 36-45 stated 1 disagreed, 3 neither, 10 agreed and 6 strongly agreed. Teachers of age 46 and above showed 1 neither, 5 agreed and 2 strongly agreed.

Table No. 17

\begin{tabular}{cccccccc}
\hline & \multicolumn{3}{c}{$\begin{array}{c}\text { Q7: I always reach my performance target } \\
\text { because of performance appraisal }\end{array}$} & \multirow{2}{*}{ Total } \\
\cline { 3 - 6 } & $\begin{array}{c}\text { strongly } \\
\text { disagree }\end{array}$ & disagree & neither & agree & strongly \\
agree & \\
\cline { 3 - 6 } & $18-25$ & 0 & 0 & 0 & 2 & 0 & 2 \\
age & $26-35$ & 1 & 2 & 5 & 8 & 4 & 20 \\
& $36-45$ & 0 & 0 & 4 & 13 & 3 & 20 \\
& 46 and above & 0 & 0 & 0 & 6 & 2 & 8 \\
& 1 & 2 & 9 & 29 & 9 & 50 \\
\hline
\end{tabular}

This table shows analysis that I always reach my performance target because of performance appraisal. Out of 50, 2 teachers between age of 18-25 agreed to the point. Teachers between 26-35, 1 strongly disagreed, 2 disagreed, 5 neither, 8 agreed and 4 strongly agreed. From amongst teachers between 36between 46 and above showed, 6 agreed and 2 strongly agreed. 


\section{Table No. 18:}

\begin{tabular}{|c|c|c|c|c|c|c|c|}
\hline & \multicolumn{5}{|c|}{$\begin{array}{l}\text { Q8: Performance appraisal motivates employee to } \\
\text { make sound decisions and appropriate choices }\end{array}$} & \multirow[t]{2}{*}{ Total } \\
\hline & & $\begin{array}{l}\text { strongly } \\
\text { disagree }\end{array}$ & disagree & Neither & agree & $\begin{array}{c}\text { strongly } \\
\text { agree }\end{array}$ & \\
\hline \multirow{4}{*}{ Age } & $18-25$ & 0 & 1 & 1 & 0 & 0 & 2 \\
\hline & $26-35$ & 1 & 3 & 8 & 7 & 1 & 20 \\
\hline & $36-45$ & 2 & 2 & 6 & 9 & 1 & 20 \\
\hline & $\begin{array}{l}46 \text { and } \\
\text { above }\end{array}$ & 1 & 0 & 3 & 4 & 0 & 8 \\
\hline Total & & 4 & 6 & 18 & 20 & 2 & 50 \\
\hline
\end{tabular}

This table shows analysis that performance appraisal system motivates employee to make sound decisions and appropriate choices. Out of 50, 1 teacher ranging between age of 18-25 agreed and 1 responded neither. 1 teacher between 26-35 agreed, 3 disagreed, 8 neither, 7 agreed and 1 strongly agreed. Teachers between 36-45 responded 2 strongly disagreed, 2 disagreed, 6 neither, 9 agreed and 1 strongly agreed. Teacher 46 and above stated 1 strongly agreed, 3 neither and 4 agreed.

Table No. 19

\begin{tabular}{|c|c|c|c|c|c|c|c|}
\hline & \multicolumn{5}{|c|}{$\begin{array}{l}\text { Q9: Performance appraisal system decreases } \\
\text { employee turnover }\end{array}$} & \multirow[t]{2}{*}{ Total } \\
\hline & & $\begin{array}{l}\text { strongly } \\
\text { disagree }\end{array}$ & disagree & neither & Agree & $\begin{array}{l}\text { strongly } \\
\text { agree }\end{array}$ & \\
\hline \multirow{4}{*}{ age } & $18-25$ & 0 & 0 & 0 & 2 & 0 & 2 \\
\hline & $26-35$ & 0 & 2 & 3 & 12 & 3 & 20 \\
\hline & $36-45$ & 2 & 5 & 2 & 5 & 6 & 20 \\
\hline & $\begin{array}{l}46 \text { and } \\
\text { above }\end{array}$ & 0 & 2 & 1 & 5 & 0 & 8 \\
\hline Total & & 2 & 9 & 6 & 24 & 9 & 50 \\
\hline
\end{tabular}

Table no 19 shows analysis about performance appraisal system decreases employee turnover. Out of 50, 2 teachers between 18-25 years of age agreed to the point. Age group 26-35 shows 2 disagreed, 3 neither, 12 agreed and 3 strongly agreed. Age group 36-45 shows 2 strongly disagreed, 5 disagreed, 2 neither, 5 agreed and 6 strongly agreed. Teachers of age between 46 and above shows 2 disagreed, 1 neither and 5 agreed. 


\section{Table No. 20}

\begin{tabular}{|c|c|c|c|c|c|c|c|}
\hline & \multicolumn{5}{|c|}{$\begin{array}{l}\text { Q10: Performance appraisal system satisfies the } \\
\text { employee with the opportunity to get a better } \\
\text { position in the organization }\end{array}$} & \multirow[t]{2}{*}{ Total } \\
\hline & & $\begin{array}{l}\text { strongly } \\
\text { disagree }\end{array}$ & Disagreed & neither & Agree & $\begin{array}{c}\text { strongly } \\
\text { agree }\end{array}$ & \\
\hline \multirow{4}{*}{ age } & $18-25$ & 0 & 0 & 0 & 2 & 0 & 2 \\
\hline & $26-35$ & 0 & 5 & 3 & 9 & 3 & 20 \\
\hline & $36-45$ & 1 & 6 & 3 & 7 & 3 & 20 \\
\hline & $\begin{array}{l}46 \text { and } \\
\text { above }\end{array}$ & 0 & 2 & 0 & 5 & 1 & 8 \\
\hline Total & & 1 & 13 & 6 & 23 & 7 & 50 \\
\hline
\end{tabular}

Table 20 shows that out of 50, 2 teachers aged between 18-25 agreed to the point that performance appraisal system satisfies the employee with the opportunity to get a better position in the organization. 5 Teachers of age between 26-35 disagreed, 3 neither, 9 agreed and 3 strongly agreed. 1 teacher of age between 36-45 strongly disagreed, 6 disagreed, 3 neither, 7 agreed and 3 strongly agreed. 2 teachers of age 46 and above disagreed, 5 agreed and 1 strongly agreed.

\section{Educational qualification}

\section{Table No. 21}

\begin{tabular}{|c|c|c|c|c|c|}
\hline & \multicolumn{3}{|c|}{$\begin{array}{c}\text { Q1: I am aware of the performance } \\
\text { appraisal technique of my } \\
\text { organization }\end{array}$} & \multirow[t]{2}{*}{ Total } \\
\hline & & $\begin{array}{l}\text { strongly } \\
\text { disagree }\end{array}$ & agree & strongly agree & \\
\hline & Inter & 0 & 4 & 1 & 5 \\
\hline & Bachelor & 0 & 11 & 7 & 18 \\
\hline $\begin{array}{l}\text { Educational } \\
\text { qualification }\end{array}$ & $\begin{array}{l}\text { profession } \\
\text { al } \\
\text { teaching } \\
\text { degree }\end{array}$ & 0 & 4 & 7 & 11 \\
\hline & Masters & 1 & 10 & 5 & 16 \\
\hline Total & & 1 & 29 & 20 & 50 \\
\hline
\end{tabular}

Table no 21 shows analysis that I am aware of the performance appraisal technique of my organization. Out of 50,4 teachers with inter qualification 
agreed and 1 strongly agreed. 11 teachers with bachelor's qualification agreed to the point and 7 strongly agreed. 4 teachers with professional teacher's degree agreed and 7 strongly agreed. 1 teacher holding master's degree strongly disagreed to the point, 10 agreed and 5 strongly agreed.

Table No 22

\begin{tabular}{|c|c|c|c|c|}
\hline & & $\begin{array}{r}\text { Q2: Are } \\
\text { objective } \\
\text { app1 }\end{array}$ & $\begin{array}{l}\text { aware of the } \\
\text { he performance } \\
\text { l system }\end{array}$ & Total \\
\hline & & agree & strongly agree & \\
\hline & Inter & 4 & 1 & 5 \\
\hline & Bachelor & 10 & 8 & 18 \\
\hline $\begin{array}{l}\text { Educational } \\
\text { qualification }\end{array}$ & $\begin{array}{l}\text { professional } \\
\text { teaching } \\
\text { degree }\end{array}$ & 5 & 6 & 11 \\
\hline & Masters & 13 & 3 & 16 \\
\hline Total & & 32 & 18 & 50 \\
\hline
\end{tabular}

This table shows analysis about are you aware of the objective of the performance appraisal system. 4 teachers with inter qualification agreed and 1 strongly agreed. 10 teachers with bachelor's qualification agreed and 8 strongly agreed. 5 teachers holding professional degree agreed and 6 strongly agreed. 13 teachers holding master's degree agreed and 3 teachers strongly agreed to the point.

Table No 23

\begin{tabular}{|c|c|c|c|c|c|c|}
\hline & & \multicolumn{4}{|c|}{$\begin{array}{c}\text { Q3: Performance appraisal system } \\
\text { helps organization in achieving } \\
\text { goals }\end{array}$} & \multirow[t]{2}{*}{ Total } \\
\hline & & disagree & neither & agree & $\begin{array}{c}\text { strongly } \\
\text { agree }\end{array}$ & \\
\hline & inter & 0 & 2 & 2 & 1 & 5 \\
\hline & bachelor & 0 & 5 & 8 & 5 & 18 \\
\hline $\begin{array}{l}\text { Educational } \\
\text { qualification }\end{array}$ & $\begin{array}{l}\text { professional } \\
\text { teaching } \\
\text { degree }\end{array}$ & 1 & 3 & 4 & 3 & 11 \\
\hline & masters & 1 & 1 & 10 & 4 & 16 \\
\hline Total & & 2 & 11 & 24 & 13 & 50 \\
\hline
\end{tabular}


Table no 23 shows performance appraisal system helps organization in achieving goals. Out of 50 teachers of inter qualification stated 2 neither, 2 agreed and 1 strongly agreed. Teachers of bachelor's qualification showed up 5 neither, 8 agreed and 5 strongly agreed. Teachers holding professional teaching degree stated 1 disagreed, 3 neither, 4 agreed and 3 strongly agreed. Teachers with master's qualification stated 1 disagreed, 1 neither, 10 agreed and 4 strongly agreed.

Table No 24

\begin{tabular}{|c|c|c|c|c|c|c|c|}
\hline & \multicolumn{5}{|c|}{$\begin{array}{l}\text { Q4: Should organization have to make a } \\
\text { fixed duration for performance appraisal }\end{array}$} & \multirow[t]{2}{*}{ Total } \\
\hline & & $\begin{array}{l}\text { strongly } \\
\text { disagree }\end{array}$ & disagree & neither & Agree & $\begin{array}{c}\text { strongly } \\
\text { agree }\end{array}$ & \\
\hline & inter & 0 & 0 & 2 & 2 & 1 & 5 \\
\hline & bachelor & 2 & 1 & 7 & 6 & 2 & 18 \\
\hline $\begin{array}{l}\text { Educational } \\
\text { qualification }\end{array}$ & $\begin{array}{l}\text { professio } \\
\text { nal } \\
\text { teaching } \\
\text { degree }\end{array}$ & 1 & 2 & 5 & 2 & 1 & 11 \\
\hline & masters & 0 & 2 & 2 & 8 & 4 & 16 \\
\hline Total & & 3 & 5 & 16 & 18 & 8 & 50 \\
\hline
\end{tabular}

Table no 24 shows should organization have to make a fixed duration for performance appraisal. 2 teachers with inter qualification stated neither, 2 agreed and 1 strongly agreed. Teachers with bachelor qualification showed 2 strongly disagreed, 1 disagreed, 7 neither, 6 agreed and 2 strongly agreed. Teachers with professional teaching degree stated 1 strongly agreed, 2 disagreed, 5 neither, 2 agreed and 1 strongly agreed. Teacher's with master's qualification stated 2 disagreed, 2 neither, 8 agreed and 4 strongly agree.

Table No 25

\begin{tabular}{|c|c|c|c|c|c|}
\hline & & $\begin{array}{l}\text { Q5: I } \\
\text { apprecia } \\
\text { your co- }\end{array}$ & $\begin{array}{l}\text { import } \\
\text { n for } y \\
\text { rker an }\end{array}$ & $\begin{array}{l}\text { to get } \\
\text { work by } \\
\text { upervisor }\end{array}$ & Total \\
\hline & & neither & agree & $\begin{array}{c}\text { strongly } \\
\text { agree }\end{array}$ & \\
\hline Educational & inter & 1 & 3 & 1 & 5 \\
\hline qualification & bachelor & 1 & 13 & 4 & 18 \\
\hline
\end{tabular}




$\begin{array}{lcccc}\text { professional } & 2 & 7 & 2 & 11 \\ \text { teaching degree } & & & & \\ \text { masters } & 0 & 9 & 7 & 16 \\ & 4 & 32 & 14 & 50\end{array}$

Table no 25 is it important to get appreciation for your work by your co-worker and supervisor. Teachers with bachelor qualification stated 1 neither, 13 agreed and 4 agreed. Teachers with professional teaching degree stated 2 neither, 7 agreed and 2 strongly agreed. 9 teachers with master's qualification agreed and 7 strongly agreed.

\section{Table No 26}

\begin{tabular}{|c|c|c|c|c|c|c|c|}
\hline & \multicolumn{5}{|c|}{$\begin{array}{l}\text { Q6: Performance appraisal system helps } \\
\text { me to find out about my level of } \\
\text { performance }\end{array}$} & \multirow[t]{2}{*}{ Total } \\
\hline & & $\begin{array}{l}\text { strongly } \\
\text { disagree }\end{array}$ & $\begin{array}{c}\text { disagr } \\
\text { ee }\end{array}$ & $\begin{array}{c}\text { neithe } \\
\text { r }\end{array}$ & agree & $\begin{array}{l}\text { strongly } \\
\text { agree }\end{array}$ & \\
\hline & inter & 0 & 0 & 1 & 4 & 0 & 5 \\
\hline & bachelor & 0 & 2 & 2 & 11 & 3 & 18 \\
\hline $\begin{array}{l}\text { Educational } \\
\text { qualification }\end{array}$ & $\begin{array}{l}\text { profession } \\
\text { al teaching } \\
\text { degree }\end{array}$ & 0 & 0 & 1 & 5 & 5 & 11 \\
\hline & masters & 1 & 1 & 3 & 5 & 6 & 16 \\
\hline Total & & 1 & 3 & 7 & 25 & 14 & 50 \\
\hline
\end{tabular}

Table no 6 shows that performance appraisal system helps me to find out about my level of performance. Out of 50,1 teacher with inter qualification stated neither and 4 agreed. Teachers with bachelor qualification stated 2 disagreed, 2 neither, 11 agreed and 3 strongly agreed. Teachers with professional teaching degree stated 1 neither, 5 agreed and 5 strongly agreed. Teachers with master's qualification showed up 1 strongly disagreed, 1 disagreed, 3 nether, 5 agreed and 6 strongly agree.

Table No 27

\begin{tabular}{ccccccc} 
& \multicolumn{4}{c}{$\begin{array}{l}\text { Q7: I always reach my performance target } \\
\text { because of performance appraisal }\end{array}$} & \multirow{2}{*}{ Total } \\
\cline { 2 - 4 } inter & $\begin{array}{c}\text { strongly } \\
\text { disagree }\end{array}$ & Disagree & neither & agree & strongly \\
agree & \\
& 0 & 0 & 1 & 4 & 0 & 5 \\
\hline \hline
\end{tabular}


Educational onal

$\begin{array}{llllcll}\text { bachelor } & 0 & 1 & 3 & 12 & 2 & 18 \\ \text { professi } & 0 & 0 & 2 & 5 & 4 & 11\end{array}$

qualification teaching

$$
\text { degree }
$$

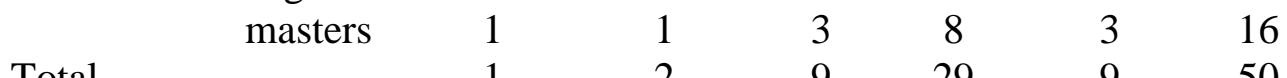

\begin{tabular}{lllllll} 
Total & 1 & 2 & 9 & 29 & 9 & 50 \\
\hline
\end{tabular}

Table no 7 shows I always reach my performance target because of performance appraisal. Teachers with inter qualification 1 neither and 4 agreed. Teachers with bachelor qualification showed 1 disagreed, 3 neither, 12 agreed and 2 strongly agreed. Teachers with professional teaching degree showed up 2 neither, 5 agreed and 4 strongly agreed. Teachers with masters qualification stated 1 strongly disagreed, 1 disagreed, 3 neither, 8 agreed and 3 strongly agreed to the point.

\section{Table No 28}

\begin{tabular}{|c|c|c|c|c|c|c|c|}
\hline & \multicolumn{5}{|c|}{$\begin{array}{l}\text { Q8: Performance appraisal motivates } \\
\text { employee to make sound decisions and } \\
\text { appropriate choices }\end{array}$} & \multirow[t]{2}{*}{ Total } \\
\hline & & $\begin{array}{l}\text { strongly } \\
\text { disagree }\end{array}$ & disagree & neither & Agree & $\begin{array}{l}\text { strongl } \\
\text { y agree }\end{array}$ & \\
\hline & Inter & 0 & 1 & 3 & 1 & 0 & 5 \\
\hline & bachelor & 1 & 2 & 8 & 6 & 1 & 18 \\
\hline $\begin{array}{l}\text { Educational } \\
\text { qualification }\end{array}$ & $\begin{array}{l}\text { profession } \\
\text { al teaching } \\
\text { degree }\end{array}$ & 3 & 1 & 3 & 4 & 0 & 11 \\
\hline & masters & 0 & 2 & 4 & 9 & 1 & 16 \\
\hline Total & & 4 & 6 & 18 & 20 & 2 & 50 \\
\hline
\end{tabular}

Table no 8 shows performance appraisal motivates employee to make sound decisions and appropriate choices. 1 teacher with inter qualification disagreed, 3 neither and 1 agreed. Teachers with bachelor qualification stated 1 strongly agreed, 2 disagreed, 8 neither, 6 agreed and 1 strongly agreed. Teachers with professional teaching degree showed up 3 strongly disagree, 1 disagree, 3 neither and 4 agreed. Teachers with master's qualification stated 2 disagree, 4 neither, 9 agree and 1 strongly agree. 


\section{Table No 29}

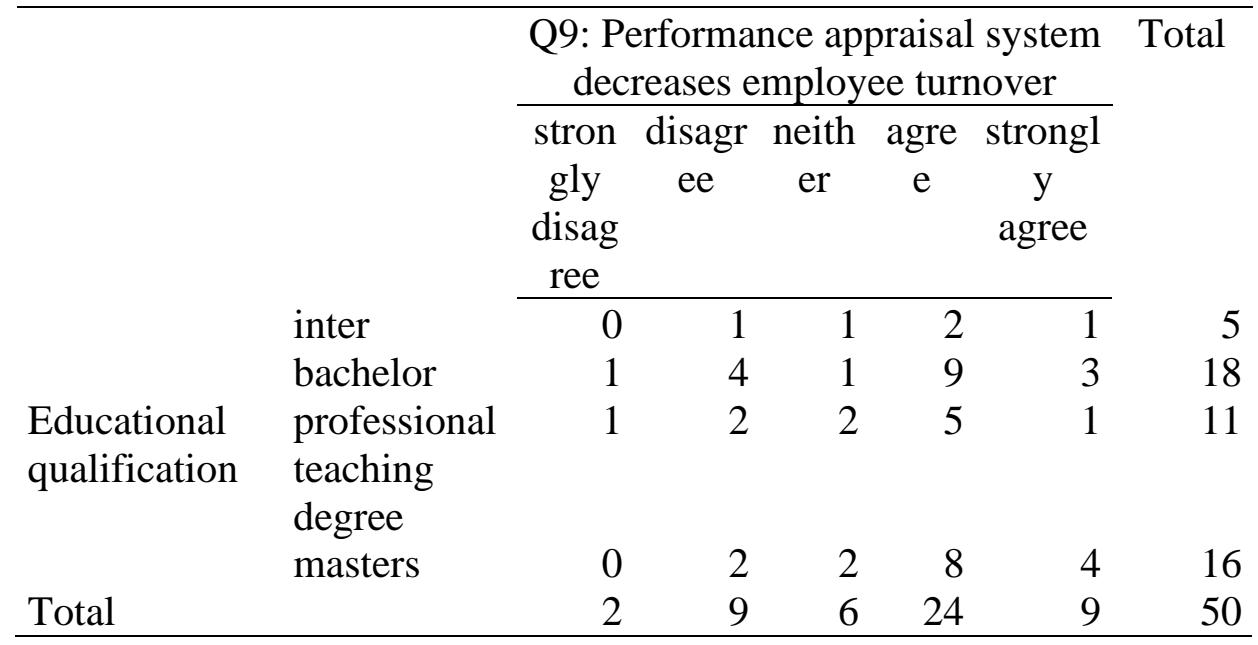

Table no 29 shows analysis of performance appraisal system decreases employee turnover. Teachers with inter qualification stated 1 disagree, 1 neither, 2 agreed and 1 strongly agreed. Teachers with bachelor qualification stated 1 strongly disagree, 4 disagree, 1 neither, 9 agree and 3 strongly agree. Teachers with professional teaching degree stated 1 strongly disagree, 2 disagree, 2 neither, 5 agree and 1 strongly agree. Teachers with master's degree stated 2 disagree, 2 neither, 8 agree and 4 strongly agree.

\section{Table No 30}

\begin{tabular}{|c|c|c|c|c|c|c|c|}
\hline & \multicolumn{5}{|c|}{$\begin{array}{c}\text { Q10: Performance appraisal system satisfies } \\
\text { the employee with the opportunity to get a } \\
\text { better position in the organization }\end{array}$} & \multirow[t]{2}{*}{ Total } \\
\hline & & $\begin{array}{l}\text { strongly } \\
\text { disagree }\end{array}$ & $\begin{array}{c}\text { disagre } \\
\mathrm{e}\end{array}$ & neither & Agree & $\begin{array}{c}\text { strongly } \\
\text { agree }\end{array}$ & \\
\hline & inter & 0 & 1 & 1 & 3 & 0 & 5 \\
\hline & bachelor & 1 & 4 & 2 & 10 & 1 & 18 \\
\hline $\begin{array}{l}\text { Educational } \\
\text { qualification }\end{array}$ & $\begin{array}{l}\text { profession } \\
\text { al teaching } \\
\text { degree }\end{array}$ & 0 & 3 & 2 & 4 & 2 & 11 \\
\hline & masters & 0 & 5 & 1 & 6 & 4 & 16 \\
\hline Total & & 1 & 13 & 6 & 23 & 7 & 50 \\
\hline
\end{tabular}

Table no 30 shows analysis about performance appraisal system satisfies the employee with the opportunity to get a better position in the organization. Out 
of 50, 1 teacher with inter qualification disagreed, 1 responded neither and 3 agreed to the point. Teachers with bachelor qualification responded 1 strongly disagree, 4 disagree, 2 neither, 10 agree and 1 strongly agree. Teachers having professional degree stated 3 disagree, 2 neither, 4 agree and 2 strongly agree. Teachers with master's qualification responded 5 disagree, 1 neither, 6 agree and 4 strongly agree.

\section{DISCUSSION}

The conclusion which I take into my thesis is that performance appraisal system is a very important aspect of an organization because employees wants to get appreciated or differentiated regarding to the amount of work or service they are providing to their organization. Therefore, organizations need to install fair performance appraisal system to motivate their employees to contribute more.

In my research, my overall observation, introducing a performance appraisal system into organization helps management to categorize employees into performers and non-performers. This is done to identify the strengths and weaknesses of employees and help them to set developmental goals. When a performance appraisal system is managed well it can help employees to achieve more which ultimately results in job satisfaction. An appraisal system will assess staff performance against a list of set objectives and will help to guide employees on a course of future development.

\section{RECOMMENDATIONS}

We come up with that the whole performance appraisal system should be kept transparent and free from bias in the future. Implement more methods of performance appraisal and update the employees about the type of method used for performance evaluation. More training should be given to mentally stressed staff which improve the potential and results in top appraisal points. Suggestions could be obtained from employees regarding framing the performance appraisal system.

\section{REFERENCES}

Abraham, S. E., Karns, L. A., Shaw, K., \& Mena, M. A. (2001). Managerial competencies and the managerial performance appraisal process. Journal of Management Development, 20(10), 842-852.

Anderson, E. W., \& Sullivan, M. W. (1993). The antecedents and consequences of 
customer satisfaction for firms. Marketing science, 12(2), 125-143.

Balzer, W. K., Smith, P. C., \& Kravitz, D. A. (1990). User's manual for the Job Descriptive Index (JDI) and the Job in General (JIG) scales. Department of Psychology, Bowling Green State University.

Banks, C. G., \& Murphy, K. R. (1985). Toward narrowing the research-practice gap in performance appraisal. Personnel Psychology, 38(2), 335-345.

Bernardin, H. J., \& Beatty, R. W. (1984). Performance appraisal: Assessing human behavior at work (p. 212). Boston: Kent Publishing Company.

Bowman, J. S. (1994). At last, an alternative to performance appraisal: Total quality management. Public Administration Review, 129-136.

Bruce, W. M., \& Blackburn, J. W. (Eds.). (1992). Balancing job satisfaction \& performance: A guide for human resource professionals. Praeger Pub Text.

Burke, R. J., Weitzel, W., \& Weir, T. (1978). Characteristics of effective employee performance review and development interviews: replication and extension 1. Personnel Psychology, 31(4), 903-919.

Cardy, R. L., \& Dobbins, G. H. (1994). Performance appraisal: The influence of liking on cognition. Advances in managerial cognition and organizational information processing, 5, 115-140.

Cranny, C. J., Smith, P. C., \& Stone, E. F. (Eds.). (1992). Job satisfaction: How people feel about their jobs and how it affects their performance. Lexington Books.

Cranny, C. J., Smith, P. C., \& Stone, E. F. (Eds.). (1992). Job satisfaction: How people feel about their jobs and how it affects their performance. Lexington Books.

Ferris, G. R., Rowland, K. M., \& Buckley, M. R. (1990). Human resource management: Perspectives and issues. Allyn \& Bacon.

Herzberg, F. I. (1966). Work and the nature of man.

Hopkins, A. H. (1983). Work and job satisfaction in the public sector. Totowa, NJ: Rowman \& Allanheld.

Hoppock, R. (1935). Job satisfaction.

Hoy, W. K., \& Miskel, C. G. (1987). Theory research and practice. Educational Administration.

Hrebiniak, L. G., \& Alutto, J. A. (1972). Personal and role-related factors in the development of organizational commitment. Administrative science quarterly, 555-573.

Jeanmarie, T. M. (2008). The relationship between principals' perceptions of performance appraisal and level of job satisfaction (Doctoral dissertation, Wayne State University).

Jette, R. D., \& Wertheim, E. G. (1994). Performance appraisal. Human resources management and development handbook, 281-282.

Judge, T. A., \& Ferris, G. R. (1993). Social context of performance evaluation decisions. Academy of management journal, 36(1), 80-105.

Lado, A. A., \& Wilson, M. C. (1994). Human resource systems and sustained 
Pakistan Journal of Educational Research, Vol 1, Issue 2 (2018) Performance appraisal... competitive advantage: A competency-based perspective. Academy of management review, 19(4), 699-727.

Landy, F. J., \& Farr, J. L. (1980). Performance rating. Psychological Bulletin, 87(1), 72.

Locke, E. A. (1969). What is job satisfaction?. Organizational behavior and human performance, 4(4), 309-336.

Miner Jr, F. C. (1984). Group versus individual decision making: An investigation of performance measures, decision strategies, and process losses/gains. Organizational Behavior and Human Performance, 33(1), 112-124.

Miskel, C., Glasnapp, D., \& Hatley, R. (1975). A test of the inequity theory for job satisfaction using educators' attitudes toward work motivation and work incentives.Educational Administration Quarterly, 11(1), 38-54.

Mohrman Jr, A. M., Resnick-West, S. M., Lawler III, E. E., Driver, M. J., Von Glinow, M. A., \& Prince, J. B. (1989). Designing performance appraisal systems: Aligning appraisals and organizational realities. Jossey-Bass.

Mohrman Jr, A. M., Resnick-West, S. M., Lawler III, E. E., Driver, M. J., Von Glinow, M. A., \& Prince, J. B. (1989). Designing performance appraisal systems: Aligning appraisals and organizational realities. Jossey-Bass.

Murphy, K. R., \& Cleveland, J. N. (1991). Performance appraisal: An organizational perspective. Allyn \& Bacon.

Ostroff, C. (1992). The relationship between satisfaction, attitudes, and performance: An organizational level analysis. Journal of applied psychology, 77(6), 963.

Pearce, J. L., \& Porter, L. W. (1986). Employee responses to formal performance appraisal feedback. Journal of Applied Psychology, 71(2), 211.

Porter, L. W., Lawler, E. E., \& Hackman, J. R. (1975). Behavior in organizations.

Roethlisberger, F. J., \& Dickson, W. J. (2003). Management and the Worker 5, Psychology press.

Schneier, C. E., Shaw, D. G., \& Beatty, R. W. (1991). Performance measurement and management: A tool for strategy execution. Human resource management, 30(3), 279-301.

Swan, W. S., \& Margulies, P. (1991). How to do a superior performance appraisal. John Wiley \& Sons Inc. 